\title{
Retinoblastoma cT1c TNM Finding v7
}

National Cancer Institute

\section{Source}

National Cancer Institute. Retinoblastoma CT1C TNM Finding v7. NCI Thesaurus. Code C88757.

At least one tumor is greater than $3 \mathrm{~mm}$ in largest dimension or located closer than 1.5 $\mathrm{mm}$ to the optic nerve or fovea, with retinal detachment or subretinal fluid beyond $5 \mathrm{~mm}$ from the base of the tumor. (from AJCC 7th Ed.) 